\title{
Calcium levels and calcium:available phosphorus ratios in diets for white egg layers from 42 to 58 weeks of age
}

\author{
Silvana Marques Pastore ${ }^{1}$, Paulo Cezar Gomes ${ }^{1}$, Horacio Santiago Rostagno', Luiz Fernando \\ Teixeira Albino", Arele Arlindo Calderano ${ }^{1}$, Cássia Rampini Vellasco', Gabriel da Silva Viana", \\ Rodrigo Lopes de Almeida ${ }^{1}$
}

\footnotetext{
${ }^{1}$ Universidade Federal de Viçosa, MG, Brazil.
}

\begin{abstract}
The experiment was conducted to determine the nutritional requirement of calcium and the best calcium: available phosphorus ratio for commercial layers at the post-laying peak. A total of $324 \mathrm{Hy}$-Line W-36 laying hens were utilized in the period from 42 to 58 weeks of age, distributed in a completely randomized design in a $3 \times 3$ factorial arrangement, composed of three levels of calcium $(39,42$ and $45 \mathrm{~g} / \mathrm{kg})$ and three calcium:phosphorus ratios $(12.12: 1 ; 10.53: 1 ;$ and 9.30:1), totaling nine treatments with six replications and six birds per experimental unit. There was no significant effect from the calcium levels $\times$ calcium:phosphorus ratio interaction for any of the variables studied. The calcium levels and the calcium: phosphorus ratios did not affect the variables performance or egg and bone quality. At the evaluation of the calcium:phosphorus balance, as the levels of calcium of the diet were raised, the intake of calcium and phosphorus and the contents of mineral matter and calcium in the excreta increased linearly, and the retention of calcium by birds decreased linearly. With the reduction of the calcium:phosphorus ratios of the diet, intake, retention and excretion of phosphorus by layers increased. Diets containing calcium at $39 \mathrm{~g} / \mathrm{kg}$ and a calcium:phosphorus ratio of 12.12:1, corresponding to an increase in calcium of $3.51 \mathrm{~g} / \mathrm{bird} / \mathrm{day}$ and available phosphorus of $289 \mathrm{mg} / \mathrm{bird} /$ day, meet the requirements of calcium and available phosphorus of white egg layers in the period from 42 to 58 weeks of age.
\end{abstract}

Key Words: birds, mineral, performance, requirement

\section{Introduction}

Over the years, commercial layer strains have been genetically improved in order to be more productive. However, these advancements make them more demanding as for nutrition. Thus, recurring studies are necessary for the update of the nutritional requirements, for these birds to express their maximum production potential. Because the requirements of calcium and phosphorus of layers have constantly changed, special attention has been drawn to research on the requirements of these minerals for laying birds.

Calcium and phosphorus are considered the main minerals in diets for layers, due to their expressive participation in the metabolism and in the quality of the eggshell. While calcium is necessary at big quantities, phosphorus is the mineral that most encumbers the final cost of diets, even though it is required at low amounts.

Although the literature is rich in studies on the levels of these minerals for hens in the laying phase, there is controversy as for the appropriate level to be used in the diets. Vieira et al. (2011) recommended calcium at the level of $34.1 \mathrm{~g} / \mathrm{kg}$ and Dantas et al. (2010), at $41.3 \mathrm{~g} / \mathrm{kg}$ of diet, whereas Rostagno et al. (2011) recommended the levels of $40.2 \mathrm{~g} / \mathrm{kg}$ for calcium and $3.0 \mathrm{~g} / \mathrm{kg}$ for phosphorus. However, Lelis et al. (2009) indicated the level of $2.3 \mathrm{~g} / \mathrm{kg}$ for phosphorus. This divergence in the results can be explained by the fact that most studies do not take into account their relation with each other. Nevertheless, it is known that the use efficiency of these minerals is dependent on the quantity and on the interrelations existing.

The excess of calcium in the diets can cause antagonism at the absorption of minerals, influencing the maintenance of the homeostasis of these minerals. When in excess, phosphorus may hamper the release of bone calcium and the adequate mineralization of the eggshell, whereas deficiency of calcium and phosphorus might result in bad quality of the eggshell and reduction in the size and production of eggs. Thus, it is of utmost importance to consider the relations between calcium and phosphorus in the evaluation of their requirements. This nutritional practice will result in more-economical diets appropriate for birds, in addition to promoting less excretion of minerals, especially phosphorus, thus reducing the negative impact of animal production on the environment. 
Therefore, the objective of this study was to determine the nutritional requirement of calcium and the best calcium: available phosphorus ratio for white egg layers in the period from 42 to 58 weeks of age.

\section{Material and Methods}

The experiment was conducted in the facilities of the Aviculture Sector of the Departamento de Zootecnia of Universidade Federal de Viçosa, located in the state of Minas Gerais, Brazil, in the period from May to September 2009.

A total of 324 Hy-Line W-36 laying hens at 42 weeks of age and initial weight of $1.308 \pm 0.03 \mathrm{~kg}$ were utilized. Birds were distributed in a completely randomized design, in a $3 \times 3$ factorial arrangement, composed of three levels of calcium and three calcium:available phosphorus ratios, totaling nine treatments with six replications and six birds per experimental unit. Each experimental unit was comprised of three cages $(25 \times 45 \times 40 \mathrm{~cm})$, each containing two birds, provided with galvanized gutter-type feeder and drinker covering the entire front length of cages.

Birds were acquired at 40 weeks of age and housed in an enclosed experimental shed $(24 \times 8 \mathrm{~m})$ with mesh cover on the sides, ceiling height of $1.8 \mathrm{~m}$ and covered with gableroof clay tiles. The birds were managed as described in the manual of the commercial strain (Hy Line W-36, 2009) and fed according to the recommendations of Rostagno et al. (2005) up to 42 weeks of age. In this period, egg production was controlled, so as to allow standardization of their egg laying rate. Next, hens were distributed according to body weight and laying before the administration of experimental diets.

At 42 weeks of age, birds started to receive the experimental diets (Table 1), all with the same amount of energy and nutrients, except for the levels of calcium (39, 42 and $45 \mathrm{~g} / \mathrm{kg}$ ) and available phosphorus. The experimental diets were formulated with three levels of calcium, obtained

Table 1 - Composition and nutritional value of experimental diets

\begin{tabular}{|c|c|c|c|}
\hline \multirow{3}{*}{ Ingredients $(\mathrm{g} / \mathrm{kg}$ of natural matter) } & \multicolumn{3}{|c|}{ Calcium levels (g/kg) } \\
\hline & 39 & 42 & 45 \\
\hline & \multicolumn{3}{|c|}{ Calcium:available phosphorus ratios } \\
\hline Ground corn & 538 & 538 & 538 \\
\hline Soybean meal & 239.5 & 239.5 & 239.5 \\
\hline Soybean oil & 42.8 & 42.8 & 42.8 \\
\hline DL-methionine $99 \%$ & 2.3 & 2.3 & 2.3 \\
\hline L-lysine $\mathrm{HCl} 78,4 \%$ & 1 & 1 & 1 \\
\hline Tryptophan $99 \%$ & 0.2 & 0.2 & 0.2 \\
\hline Vitamin premix $^{1}$ & 1 & 1 & 1 \\
\hline Potassium carbonate & 0.3 & 0.3 & 0.3 \\
\hline Mineral premix ${ }^{2}$ & 0.5 & 0.5 & 0.5 \\
\hline Washed sand (inert) & $24.8 / 23.8 / 22.7$ & $16.0 / 15.0 / 13.8$ & $7.3 / 6.1 / 5.0$ \\
\hline Total & 1000.00 & 1000.00 & 1000.00 \\
\hline \multicolumn{4}{|l|}{ Calculated nutritional composition } \\
\hline Crude protein $(\mathrm{g} / \mathrm{kg})$ & 174.7 & 174.7 & 174.7 \\
\hline Metabolizable energy (kcal/kg) & 2.900 & 2.900 & 2.900 \\
\hline Calcium $(\mathrm{g} / \mathrm{kg})$ & 39.0 & 42.0 & 45.0 \\
\hline Available phosphorus (g/kg) & $3.22 / 3.70 / 4.19$ & $3.46 / 3.99 / 4.52$ & $3.71 / 4.27 / 4.84$ \\
\hline Digestible lysine $(\mathrm{g} / \mathrm{kg})$ & 8.4 & 8.4 & 8.4 \\
\hline Digestible methionine + cystine $(\mathrm{g} / \mathrm{kg})$ & 7.6 & 7.6 & 7.6 \\
\hline Digestible threonine $(\mathrm{g} / \mathrm{kg})$ & 6.0 & 6.0 & 6.0 \\
\hline Digestible tryptophan $(\mathrm{g} / \mathrm{kg})$ & 1.9 & 1.9 & 1.9 \\
\hline Digestible valine $(\mathrm{g} / \mathrm{kg})$ & 7.6 & 7.6 & 7.6 \\
\hline Digestible arginine $(\mathrm{g} / \mathrm{kg})$ & 10.4 & 10.4 & 10.4 \\
\hline Digestible phenylalanine + tyrosine $(\mathrm{g} / \mathrm{kg})$ & 14.8 & 14.8 & 14.8 \\
\hline Digestible isoleucine $(\mathrm{g} / \mathrm{kg})$ & 7.0 & 7.0 & 7.0 \\
\hline
\end{tabular}


with the addition of limestone (50\% fine and 50\% coarse) and three calcium:available phosphorus ratios (12.12:1; 10.53:1; and 9.30:1), obtained with supplementation of nine levels of available phosphorus $(3.22 ; 3.70 ; 4.19 ; 3.46 ; 3.99$; $4.52 ; 3.71 ; 4.27$; and $4.84 \mathrm{~g} / \mathrm{kg}$ ), which could be achieved with addition of dicalcium phosphate (medium texture), so as to provide the three calcium:available phosphorus ratios studied within each calcium level. The other nutrients contained in the diets met the recommendations by Rostagno et al. (2005); for the calculation of the diet, the intake was estimated at $95 \mathrm{~g} / \mathrm{bird} /$ day.

The lighting program adopted was of 17 hours of light daily. The temperature within the shed was monitored once daily, at $16 \mathrm{~h} 00$, by three thermometers of maximum and minimum, distributed in the shed, placed at the height of birds.

The diets were supplied daily, at two times: $8 \mathrm{~h} 00$ and $16 \mathrm{~h} 00$, providing birds feed and water ad libitum during all the experimental period. The experimental period had duration of 16 weeks, divided in four subperiods of 28 days and concluded when birds completed 58 weeks of age.

At the end of each subperiod, the feed leftovers from feeders and buckets were weighed and the feed intake was measured. Egg production was recorded daily, and egg weight was calculated as the average of the last five days of each subperiod. At the calculation of egg mass, the average daily egg production was multiplied by the average egg weight divided by 100 . The conversions per mass and per egg dozen were obtained by the ratio between feed intake and mass and egg dozens produced, respectively. Birds were weighed at the beginning and end of the experiment, and the average weight gain could be calculated by the difference between the weightings.

The specific gravity was evaluated utilizing all the intact eggs collected on the 23rd, 24th and 25th days of each subperiod. Eggs were immersed in saline solutions of density from 1.055 to $1.100 \mathrm{~g} / \mathrm{cm}^{3}$, with intervals of $0.005 \mathrm{~g} / \mathrm{cm}^{3}$ between them. The density of solutions was measured by decimeter. For the calculation of eggs discarded, all eggs with a thin shell, those whose shell had a crack and those with no shell were considered.

During the last three days of each subperiod, two eggs of each experimental unit were separated daily for conduction of analyses of egg quality. The total weight of eggs was determined, and eggs were subsequently cracked and their components were separated. The yolk was weighed right after cracking the eggs, and shells were washed and left to dry in the air before being weighed. The weight of the albumen was obtained by the difference between total egg weight and weight of yolk and shell.
The shell thickness was a result from the three readings performed at three different sites of the equatorial region of the same shell, utilizing a digital caliper with $0.01 \mathrm{~mm}$ precision. At the measurement of the shell, its membranes were included. For the determination of the dry matter and mineral matter, shells were ground and dried in oven at $105{ }^{\circ} \mathrm{C}$ for 16 hours and burned in a muffle furnace at $600{ }^{\circ} \mathrm{C}$ for four hours. For the determination of the contents of calcium and phosphorus in the shell, mineral solution was prepared by means of wet procedures. From the mineral solution, the calcium contents were determined through atomic absorption spectrometry and the phosphorus contents by colorimetry, according to the methodology described by Silva \& Queiroz (2002). The results were expressed on a dry matter basis.

At the end of the experiment (birds at 58 weeks of age), two birds per experimental unit ( 108 birds) were slaughtered and the left tibia was collected for determination of the mineral matter, calcium and bone phosphorus. For these determinations, tibiae were cleaned, weighed, pre-scoured with petroleum ether in Soxhlet extractor for four hours, and then dried in a forced-ventilation oven at $55^{\circ} \mathrm{C}$ for 72 hours. Afterwards, tibiae were once again weighed and compressed and ground in a ball mill. From this material, the dry and mineral matters and the contents of calcium and phosphorus were determined, following the methodology described by Silva \& Queiroz (2002). The results were expressed on a defatted dry matter basis.

For the determination of the calcium:phosphorus balance, 162 birds (three replications of each treatment) at 58 weeks of age were utilized during five days. The feed intake was measured by weighing the feed from the feeders and buckets at the beginning and end of this period. The calcium and phosphorus intake was calculated by the feed intake in that period multiplied by the level of calcium and phosphorus of the treatment to be determined, divided by 100. During this period, metal trays coated with plastic were placed under the cages to allow total collection of excreta, which was performed twice a day, at $8 \mathrm{~h} 00$ and $16 \mathrm{~h} 00$. The excreta collected in each experimental unit, after removal of feathers, feed residues and other sources of contamination, were transferred to plastic bags properly identified and stored in a freezer. After, the content stored was thawed, weighed and homogenized per replication. An aliquot of $200 \mathrm{~g}$ was taken from this material and placed in a forced-ventilation oven at $55^{\circ} \mathrm{C}$ for 72 hours. After exposed in the air to come into equilibrium with the temperature and humidity of the environment, these aliquots were weighed and ground in a ball mill. After, the dry matter, mineral matter and contents of calcium and phosphorus were determined, according to 
the methodology described by Silva \& Queiroz (2002). The results were expressed on a dry matter basis.

The results were subjected to analysis of variance and compared by the $\mathrm{F}$ test $(\mathrm{P}<0.05)$. In the absence of calcium level $\times$ calcium:phosphorus ratio interaction, the requirement of calcium and the best calcium:phosphorus ratio were obtained by regression, utilizing computer software SAS (Statistical Analysis System, version 2.0) for Windows.

\section{Results and Discussion}

During the experimental period, the means of minimum and maximum air temperature measured within the shed were of 15 and $27{ }^{\circ} \mathrm{C}$, similar to the recommendation of the manual of the commercial strain (Hy-Line W-36, 2009), which is of 18 and $27^{\circ} \mathrm{C}$, respectively.

There was no significant effect from the interaction $(\mathrm{P}>0.05)$ between the calcium levels and the calcium: phosphorus ratios studied for any of the variables studied (Tables 2, 3, 4 and 5).

In the productive performance results (feed intake, egg laying rate, egg weight and mass and bird feed conversion and weight gain), no difference was found in function of the diets (Table 2).
The results obtained for the productive performance parameters of the layers in function of the calcium levels in the diets are in line with those found by El-Ghamry et al. (2011), who evaluated four levels of calcium between 24 and $33 \mathrm{~g} / \mathrm{kg}$ for Fayoumi laying hens in the period from 45 to 57 weeks of age and did not verify difference in egg production, egg weight and egg mass. Also, Salama et al. (2012) found that egg weight, feed conversion per egg mass and weight gain were not significantly influenced by the dietary calcium level ( $30 \mathrm{up}$ to $40 \mathrm{~g} / \mathrm{kg}$ ) for commercial layers in the period from 24 to 36 weeks of age. Like Safaa et al. (2008), who also did not find differences in egg weight, feed intake or weight gain in brown egg layers of 58 weeks of age fed diets with calcium at 35 or $40 \mathrm{~g} / \mathrm{kg}$, but keeping the calcium:phosphorus ratio of 12:1, and however observed greater egg production, egg mass and best feed conversion per egg mass and dozen eggs with calcium at the level of $40 / \mathrm{kg}$ in comparison with the level of $35 \mathrm{~g} / \mathrm{kg}$ in the diet. Different result was observed by Murata et al. (2009), who recorded greater egg production at the estimated calcium level of $40.5 \mathrm{~g} / \mathrm{kg}$ and linear effect for egg weight and feed conversion per egg dozen $(\mathrm{dz} / \mathrm{kg})$ of white egg layers fed diets with calcium levels of $37.5 ; 41.5$; or $45.5 \mathrm{~g} / \mathrm{kg}$. Considering the productive performance of white egg layers under production, Dantas et al. (2010) suggested the calcium

Table 2 - Productive performance of layers from 42 to 58 weeks of age fed diets with three levels of calcium and three calcium:available phosphorus ratios

\begin{tabular}{|c|c|c|c|c|c|c|c|c|c|c|}
\hline \multirow{2}{*}{ Variables } & \multicolumn{3}{|c|}{ Calcium levels (g/kg) } & \multicolumn{3}{|c|}{ Calcium:phosphorus ratio } & \multirow{2}{*}{ CV (\%) } & \multicolumn{3}{|c|}{$\mathrm{P}$ value } \\
\hline & 39 & 42 & 45 & $12.12: 1$ & $10.53: 1$ & 9.30:1 & & $\mathrm{Ca}$ & Rat & $\mathrm{Ca} \times$ Rat \\
\hline Feed intake (g/bird/day) & 90.26 & 90.53 & 89.64 & 90.08 & 90.25 & 90.10 & 2.40 & 0.470 & 0.970 & 0.890 \\
\hline Laying rate (egg/day) & 274 & 273 & 275 & 277 & 273 & 271 & 3.87 & 0.833 & 0.261 & 0.769 \\
\hline Egg weight (g) & 60.15 & 60.38 & 59.97 & 60.00 & 60.26 & 60.24 & 2.66 & 0.750 & 0.863 & 0.579 \\
\hline Egg mass (g/bird /day) & 50.60 & 50.06 & 50.47 & 51.08 & 50.16 & 49.89 & 4.18 & 0.734 & 0.230 & 0.552 \\
\hline Weight gain (g/bird) & 26 & 39 & 35 & 25 & 31 & 44 & 36.25 & 0.776 & 0.590 & 0.536 \\
\hline Feed conversion $(\mathrm{kg} / \mathrm{dz})$ & 1.29 & 1.31 & 1.28 & 1.27 & 1.30 & 1.30 & 4.65 & 0.310 & 0.153 & 0.782 \\
\hline Feed conversion $(\mathrm{kg} / \mathrm{kg})$ & 1.78 & 1.81 & 1.78 & 1.76 & 1.80 & 1.81 & 4.02 & 0.400 & 0.147 & 0.343 \\
\hline
\end{tabular}

$\mathrm{CV}$ - coefficient of variation; $\mathrm{Ca}$, Rat and $\mathrm{Ca} \times$ Rat - effects from the supplementation with calcium, from the calcium:available phosphorus ratio and their interaction, respectively.

Table 3 - Quality of eggs from layers from 42 to 58 weeks of age fed diets with three calcium levels and three calcium:available phosphorus ratios

\begin{tabular}{|c|c|c|c|c|c|c|c|c|c|c|}
\hline \multirow{2}{*}{ Variables } & \multicolumn{3}{|c|}{ Calcium levels (g/kg) } & \multicolumn{3}{|c|}{ Calcium:phosphorus ratio } & \multirow{2}{*}{ CV $(\%)$} & \multicolumn{3}{|c|}{$P$ value } \\
\hline & 39 & 42 & 45 & $12.12: 1$ & $10.53: 1$ & $9.30: 1$ & & $\mathrm{Ca}$ & Rat & $\mathrm{Ca} \times$ Rat \\
\hline Yolk (g) & 16.05 & 15.99 & 15.86 & 15.83 & 15.94 & 16.13 & 3.43 & 0.570 & 0.265 & 0.683 \\
\hline Albumen (g) & 39.01 & 38.76 & 38.60 & 38.73 & 38.87 & 38.78 & 2.99 & 0.578 & 0.934 & 0.110 \\
\hline Shell (g) & 5.69 & 5.68 & 5.70 & 5.68 & 5.71 & 5.67 & 3.84 & 0.933 & 0.837 & 0.677 \\
\hline Shell thickness (mm) & 0.28 & 0.27 & 0.27 & 0.27 & 0.27 & 0.27 & 4.77 & 0.384 & 0.732 & 0.833 \\
\hline Specific gravity $\left(\mathrm{g} / \mathrm{cm}^{3}\right)$ & 1.09 & 1.09 & 1.09 & 1.09 & 1.09 & 1.09 & 0.79 & 0.997 & 0.807 & 0.967 \\
\hline Mineral matter of the shell $\left(\mathrm{g} / \mathrm{kg} \mathrm{DM}^{3}\right)$ & 918.2 & 922.7 & 926.7 & 924.3 & 923.3 & 920.0 & 1.63 & 0.774 & 0.922 & 0.706 \\
\hline Calcium in the shell $(\mathrm{g} / \mathrm{kg} \mathrm{DM})$ & 294.6 & 294.6 & 294.2 & 294.2 & 290.7 & 298.4 & 6.64 & 0.459 & 0.783 & 0.380 \\
\hline Phosphorus in the shell (g/kg DM) & 0.93 & 0.93 & 0.91 & 0.91 & 0.92 & 0.93 & 7.66 & 0.473 & 0.388 & 0.674 \\
\hline Eggs discarded (egg/day) & 2 & 3 & 3 & 2 & 3 & 3 & 88.44 & 0.639 & 0.507 & 0.877 \\
\hline
\end{tabular}

$\mathrm{CV}$ - coefficient of variation; DM - dry matter; $\mathrm{Ca}$, Rat and $\mathrm{Ca} \times \mathrm{Rat}$ - effects from the supplementation with calcium, from the calcium:available phosphorus ratio and their interaction, respectively. 
level of $41.3 \mathrm{~g} / \mathrm{kg}$ and Almeida et al. (2012), at $43.1 \mathrm{~g} / \mathrm{kg}$ in the diet.

As for the effects from the calcium:phosphorus ratios on the productive performance of white egg layers, they were similar to those found by Lelis et al. (2009), who studied available phosphorus at the levels of $2.3 ; 2.9 ; 3.5$; 4.1 and $4.7 \mathrm{~g} / \mathrm{kg}$ in diets with calcium at $42 \mathrm{~g} / \mathrm{kg}$ (calcium: phosphorus ratio varying from 18.26 to $8.93: 1$ ) for brown egg layers in the period from 50 to 66 weeks of age and did not verify difference in the performance of the animals; and by Rosa et al. (2011), who studied the calcium:phosphorus ratios of 8:1;11:1 and 14:1 for brown egg layers in the period from 28 to 36 weeks of age and also did not observe effect from the calcium:phosphorus ratios on feed intake, egg laying rate, feed conversion per egg mass and egg weight.

Although the egg laying rate was not affected $(\mathrm{P}>0.05)$ by the calcium:phosphorus ratios of the diet, it could be observed that with a lowercalcium:phosphorus ratio(9.30:1), the egg laying rate was $2.16 \%$ lower than that obtained with the highest calcium:phosphorus ratio (12.12:1) (Table 2). This can be explained by the greater quantity of phosphorus contained in this diet, which could have hampered the availability of calcium, and, in an attempt to circumvent this situation, the hens reduced production, but maintained the egg quality. In this sense, Silva et al. (2008), working with different calcium:phosphorus ratios $(9: 1 ; 12: 1$ and 14:1) in diets for layers, observed that the increase in the ratio from 9:1 to 14:1 improved egg production linearly. These authors also verified effect from the calcium:phosphorus ratios on egg weight, egg mass and feed conversion per egg mass, and concluded that the calcium:phosphorus ratio of 14:1 (calcium at $42 \mathrm{~g} / \mathrm{kg}$ and phosphorus at $3 \mathrm{~g} / \mathrm{kg}$ ) would ensure satisfactory performance of brown egg layers in the period from 28 to 44 weeks of age. However, Pelícia et al. (2009a), studying different levels of calcium and available phosphorus for brown egg layers, suggested calcium and phosphorus levels of 45 and $2.5 \mathrm{~g} / \mathrm{kg}$, respectively (calcium: phosphorus ratio of 18:1), for better bird performance.

The results found for the parameters of productive performance suggest that layers from the commercial strain Hy-Line W-36 require a lower level of calcium than that studied, and the possibility that, in diets with greater calcium:available phosphorus ratios (lower level of phosphorus), calcium has its availability increased.

No significant effect $(\mathrm{P}>0.05)$ from the levels of calcium or from the calcium:phosphorus ratios was verified in the period from 42 to 58 weeks of age of white egg layers on the parameters of egg quality analyzed (Table 3 ).

The results obtained for yolk, albumen and shell weight in function of the calcium levels in the diet are consistent with those found by Abd El-Maksoud (2010) and Salama et al. (2012), who found that egg quality was not significantly affected by different calcium levels ( 32.5 up to 40 and 30 up to $40 \mathrm{~g} / \mathrm{kg}$, respectively). The results for shell weight, specific gravity and number of eggs discarded are similar to those obtained by Murata et al. (2009), who also did not observe influence from the calcium levels $(37.5 ; 41.5$ and $45.5 \mathrm{~g} / \mathrm{kg}$ ) on these variables (shell weight, specific gravity and number of eggs discarded) of white egg layers at 57 weeks of age, and by Pelícia et al. (2009a), who also did not find differences in shell thickness, number of eggs discarded and in the specific gravity of the eggs from second-cycle brown egg layers in function of the four calcium levels (30; $35 ; 40$ and $45 \mathrm{~g} / \mathrm{kg}$ ) studied. However, Safaa et al. (2008) reported improvement in the shell thickness of eggs with calcium at the level of $40 \mathrm{~g} / \mathrm{kg}$ in comparison with $35 \mathrm{~g} / \mathrm{kg}$, keeping the calcium:phosphorus ratio at 12:1, in a diet for brown egg layers in the period from 58 to 73 weeks of age.

Based on the results obtained for the characteristics of shell quality (Table 3 ) and the calcium:phosphorus balance (Table 5) with the supply of calcium, it is believed that the statement made by Roland et al. (1975) is timely; these authors affirmed that the deposition of calcium in the shell is either constant or increases significantly with increase in the levels of this mineral in the diet, for the excess of dietary calcium goes through the digestive tract without being absorbed. In this sense, Vieira et al. (2011), evaluating the calcium levels of 28,33 and $38 \mathrm{~g} / \mathrm{kg}$ for brown egg layers at 40 weeks of age, verified that the calcium levels also did not influence the calcium deposition in the shell $(\mathrm{g} / \mathrm{kg})$, as in the results obtained by Lichovnicova (2007) with commercial layers at the post-peak of laying. Thus, the efficiency of calcium deposition in the shell reduced with the increase of calcium in the diet. Vellasco et al. (2010), however, in a study with white egg layers in the period from 24 to 40 weeks of age fed diets with three calcium levels $(39 ; 42$ or $45 \mathrm{~g} / \mathrm{kg}$ ), verified linear effect from the calcium levels on the shell weight and calcium content $(\mathrm{g} / \mathrm{kg})$ in the shell.

As for the effects from the calcium:phosphorus ratio on the parameters analyzed for egg quality, these results are in line with those found by Vellasco et al. (2010). In both studies, no effect from the calcium:phosphorus ratios $(12.12: 1 ; 10.53: 1$ and $9.30: 1)$ in the diet was verified on shell weight; contents of calcium $(\mathrm{g} / \mathrm{kg})$, phosphorus $(\mathrm{g} / \mathrm{kg})$ and mineral matter $(\mathrm{g} / \mathrm{kg})$; specific gravity; and thickness of shell from eggs from white egg layers. The same happened to Almeida et al. (2012), who, evaluating the calcium levels (37, 40 and $43 \mathrm{~g} / \mathrm{kg}$ ) and calcium:available phosphorus ratios $(9.76: 1 ; 10.81: 1$ and $12.12: 1)$ in diets, also did not observe effect from the calcium:phosphorus ratios on shell 
weight, contents of calcium $(\mathrm{g} / \mathrm{kg})$, phosphorus $(\mathrm{g} / \mathrm{kg})$ and mineral matter $(\mathrm{g} / \mathrm{kg})$, thickness of shell and specific gravity, although they worked with white egg layers in second production cycle.

The phosphorus and calcium contents in the shell were not affected by the diet, even with the utilization of diets with the calcium level and calcium:phosphorus ratio below (39 $\mathrm{g} / \mathrm{kg}$ and 9.30:1) and above (42 $\mathrm{g} / \mathrm{kg}$ and 12.12:1) those recommended by Rostagno et al. (2005), of calcium at $40.2 \mathrm{~g} / \mathrm{kg}$ and calcium:phosphorus ratio of 10.72:1 for the intake of $100 \mathrm{~g} / \mathrm{bird} /$ day. However, Vellasco et al. (2010) suggested calcium at the level of $45 \mathrm{~g} / \mathrm{kg}$ and calcium: phosphorus ratio of 12.12:1 (calcium and phosphorus at $3.71 \mathrm{~g} / \mathrm{bird} /$ day and $306 \mathrm{mg} / \mathrm{bird} /$ day, respectively) for a better quality of shell from eggs from white egg layers at the laying peak, whereas Rostagno et al. (2011) indicated calcium at the level of $40.2 \mathrm{~g} / \mathrm{kg}$ and a calcium:phosphorus ratio of 13.4:1 in diets for white egg layers under production consuming $100 \mathrm{~g} /$ bird/day.

Based on the results obtained for the egg quality parameters analyzed, it is possible to affirm that the lowest calcium level and the greatest calcium:phosphorus ratio (lower concentration of phosphorus) studied were sufficient to maintain the egg quality. Thus, it is possible to formulate a diet of lower cost, more appropriate to birds, with lower excretion of minerals, especially phosphorus, thus reducing the negative impact of animal production on the environment, and even to maintain the quality of the final product.

No effect $(\mathrm{P}>0.05)$ from the calcium levels or calcium: phosphorus ratios was observed on the bone characteristics of white egg layers in the period from 42 to 58 weeks of age (Table 4). Although there was increase in the levels of calcium in the diet, these levels did not affect the mineral contents in the bone, similarly to the calcium:phosphorus ratio, which also did not interfere in the levels of the minerals studied.

In spite of the results found for the deposition of phosphorus and calcium in the tibia, some studies prove that low calcium levels in diets for layers promote bone mobilization of calcium to meet the need of the bird and maintain the shell quality (Schreiweis et al., 2003; Almeida Paz, 2009). Therefore, considering the results obtained, it is possible to affirm that the lowest calcium level $(39 \mathrm{~g} / \mathrm{kg})$ was enough to meet the requirements of the layers, once the mobilization of bone calcium to maintain the shell quality was not significant $(\mathrm{P}>0.05)$. Similar results were found by Safaa et al. (2008), who did not verify effect from the levels of calcium ( 35 and $40 \mathrm{~g} / \mathrm{kg}$ ), keeping the calcium: phosphorus ratio at 12:1, in birds at 73 weeks of age. Also by Rama-Rao et al. (2003), who did not verify influence from the calcium levels on the mineral matter content of the tibia from white egg layers at 48 weeks of age, after being fed diets containing six calcium levels $(32.5 ; 35 ; 37.5$; 40; 42.5; and $45 \mathrm{~g} / \mathrm{kg}$ ) for 20 weeks, and by Pelícia et al. (2011), who did not observe influence from the calcium levels (30; 37.5 ; and $45 \mathrm{~g} / \mathrm{kg}$ ) on the calcium content in the tibia.

The effect from the calcium:phosphorus ratios on the bone characteristics are in line with Rezende et al. (2009), who evaluated the bone characteristics of laying birds subjected to four levels of available phosphorus $(1.0 ; 2.0$; 3.0 ; and $4.0 \mathrm{~g} / \mathrm{kg}$ ) in diets with $40.2 \mathrm{~g} / \mathrm{kg}$ of calcium and did not verify significant variation in the bone characteristics of white egg layers at the post-peak of laying. In a previous study, Almeida et al. (2012), evaluating calcium:available phosphorus ratios $(9.76: 1 ; 10.81: 1$ and $12.12: 1)$ in diets for white egg layers in second production cycle, also did not find influence from the calcium:phosphorus ratio on the contents of mineral matter $(\mathrm{g} / \mathrm{kg})$, calcium $(\mathrm{g} / \mathrm{kg})$ or phosphorus $(\mathrm{g} / \mathrm{kg})$ in the tibia of birds. However, Rose et al. (2011) found significant effect calcium:phosphorus rations $(8: 1,11: 1$ and 14:1) on the contents of mineral matter $(\mathrm{g} / \mathrm{kg})$, calcium $(\mathrm{g} / \mathrm{kg})$ or phosphorus $(\mathrm{g} / \mathrm{kg})$ in the tibia of brown egg layers at 36 weeks of age. These authors verified that the lowest calcium:phosphorus ratio of $8: 1$ resulted in lower mineral matter content in the tibia and higher calcium:phosphorus ratio (14:1) at greater contents of calcium $(\mathrm{g} / \mathrm{kg})$ and phosphorus $(\mathrm{g} / \mathrm{kg})$ in the tibiae.

The mineral matter contents in the excreta increased linearly $(\mathrm{P}<0.05)$ as the levels of calcium (LCA) in the diet were elevated, according to the equations $\mathrm{Y}=343.602-11.3277 \mathrm{LCA}$ $\left(\mathrm{r}^{2}=0.93\right)$, in $\mathrm{g} / \mathrm{kg}$ of dry matter and $\mathrm{Y}=7.48067-0.525966$

Table 4 - Characteristics of bones from layers at 58 weeks of age fed diets with three calcium levels and three calcium:phosphorus ratios

\begin{tabular}{|c|c|c|c|c|c|c|c|c|c|c|}
\hline \multirow{2}{*}{ Variables } & \multicolumn{3}{|c|}{ Calcium levels $(\mathrm{g} / \mathrm{kg})$} & \multicolumn{3}{|c|}{ Calcium:phosphorus ratio } & \multirow{2}{*}{$\mathrm{CV}(\%)$} & \multicolumn{3}{|c|}{$P$ value } \\
\hline & 39 & 42 & 45 & $12.12: 1$ & $10.53: 1$ & $9.30: 1$ & & $\mathrm{Ca}$ & Rat & $\mathrm{Ca} \times \mathrm{Rat}$ \\
\hline Tibia $(g)$ & 5.72 & 5.59 & 5.68 & 5.72 & 5.62 & 5.65 & 8.17 & 0.702 & 0.807 & 0.143 \\
\hline Mineral matter of the tibia ( $\mathrm{g} / \mathrm{kg}$ DDM) & 461.5 & 452.5 & 455.9 & 458.0 & 451.9 & 458.4 & 5.52 & 0.642 & 0.754 & 0.218 \\
\hline Calcium in the tibia ( $\mathrm{g} / \mathrm{kg} \mathrm{DDM})$ & 166.0 & 164.5 & 167.2 & 164.3 & 167.2 & 166.3 & 11.50 & 0.757 & 0.995 & 0.118 \\
\hline Phosphorus in the tibia ( $\mathrm{g} / \mathrm{kg}$ DDM) & 99.6 & 103.7 & 103.8 & 99.6 & 103.2 & 102.6 & 13.34 & 0.815 & 0.773 & 0.715 \\
\hline
\end{tabular}

$\mathrm{CV}$ - coefficient of variation; $\mathrm{Ca}$, Rat and $\mathrm{Ca} \times$ Rat - effects from the supplementation with calcium, from the calcium:available phosphorus ratio and their interaction, respectively; DDM - defatted dry matter. 
LCA $\left(r^{2}=0.94\right)$, in $g /$ bird/day (Table 5). The calcium contents in the excreta, both in $\mathrm{g} / \mathrm{kg}$ of dry matter and $\mathrm{g} / \mathrm{bird} / \mathrm{day}$, were also affected linearly by the calcium levels of the $\operatorname{diet}\left(\mathrm{Y}=311.806+12.9660 \mathrm{LCA}, \mathrm{r}^{2}=0.88 ; \mathrm{Y}=1.08433+\right.$ $0.0143712 \mathrm{LCA}, \mathrm{r}^{2}=0.95$, respectively), in such a way that the lowest calcium level $(39 \mathrm{~g} / \mathrm{kg})$ yielded the best result (Table 5). These results indicate a positive correlation between the concentration of calcium in the diet and the increase in its excretion, which consequently caused the elevation of the mineral matter in the excreta in function of the calcium levels in the diet. This happens because the bird only retains the necessary amount of calcium and eliminates the excess in the excreta.

Similar results were observed by Vieira et al. (2011), when evaluating the calcium levels of 28,33 and $38 \mathrm{~g} / \mathrm{kg}$ in the diet of brown egg layers from 40 weeks of age, and by Pelícia (2009b), in an experiment with brown egg layers in the period from 59 to 70 weeks of age fed diets containing the calcium levels of 30,35, 40 and $45 \mathrm{~g} / \mathrm{kg}$. These authors verified increase in the calcium excretion, in $\mathrm{g} / \mathrm{bird} / \mathrm{day}$ and in $\mathrm{g} / \mathrm{kg}$, respectively, and attributed this result to the concentration of calcium in the diet.

The levels of calcium in the diet influenced the calcium intake linearly $(\mathrm{P}<0.05 ; \mathrm{Y}=3.35823+0.199161 \mathrm{LCA}$, $\left.\mathrm{r}^{2}=0.94\right)$. This result is related to the concentration of this mineral in the diet, once the feed intake did not differ between treatments. Thus, the concentration of calcium in the diet promoted linear decrease in the retention of this mineral $\left(\mathrm{Y}=688.194-12.9660 \mathrm{LCA}, \mathrm{r}^{2}=0.88\right)$ determined in $\mathrm{g} / \mathrm{kg}$ of dry matter. When the retention of calcium was determined in $\mathrm{g} / \mathrm{bird} /$ day, there was no effect $(\mathrm{P}>0.05)$ from the calcium levels in the diet. This means that the bird kept using the same amount, regardless of the concentration of calcium in the diet, with the excess eliminated in the excreta.
Therefore, it can be affirmed that there was decreasing effect in the efficiency of calcium retention as the level of calcium in the diet increased, which was also observed by Vieira et al. (2011).

The best efficiency of calcium retention was at the lowest level of calcium of the $\operatorname{diet}(39 \mathrm{~g} / \mathrm{kg})$. This might have occurred because as the calcium levels of the diet increase, there is reduction of the biosynthesis of the protein carrier of calcium in the duodenum (Bertechini, 2006), which, in addition to damaging the functionality of the protein through increase in the intestinal $\mathrm{pH}$ (Berggard et al., 2000), decreases the absorptive efficiency of this mineral, which directly affects the retention of this mineral by birds. These results prove features of the calcium metabolism in commercial layers, because at low levels of this mineral in the diet, birds improve the utilization of dietary calcium, within their physiological limits, as a form of compensation.

The calcium levels of the diet also affected the phosphorus intake linearly $(\mathrm{Y}=0.319068+0.0191727 \mathrm{LCA}$, $\left.r^{2}=0.94\right)$, which can be explained by the fact that, in diets with higher levels of calcium, the phosphorus concentration was also higher, for in order to keep the same calcium: phosphorus ratio at the different calcium levels, it was necessary to alter the level of phosphorus in the feed, according to the calcium levels. Likewise, the calcium: phosphorus ratios (RAT) of the diet affected the phosphorus intake linearly, according to the equation $\mathrm{Y}=0.249123+$ 0.0541453 RAT $\left(r^{2}=0.97\right)$. In the diets formulated for lower calcium:phosphorus ratios, the concentration of phosphorus was higher, and since the feed intake did not differ between the calcium:phosphorus ratios, the ingestion of this mineral was greater at the different calcium:phosphorus ratios.

The calcium:phosphorus ratios affected the excretion of phosphorus determined in $\mathrm{g} / \mathrm{b}$ ird/day linearly

Table 5 - Concentration of the natural matter in the excreta and the calcium:phosphorus balance of layers at 58 weeks of age fed diets with three calcium levels and three calcium:available phosphorus levels

\begin{tabular}{|c|c|c|c|c|c|c|c|c|c|c|}
\hline \multirow{2}{*}{ Variables } & \multicolumn{3}{|c|}{ Calcium levels $(\mathrm{g} / \mathrm{kg})$} & \multicolumn{3}{|c|}{ Calcium:phosphorus ratio } & \multirow{2}{*}{$\mathrm{CV}(\%)$} & \multicolumn{3}{|c|}{$P$ value } \\
\hline & 39 & 42 & 45 & 12.12:1 & $10.53: 1$ & $9.30: 1$ & & $\mathrm{Ca}$ & Rat & $\mathrm{Ca} \times \mathrm{Rat}$ \\
\hline Mineral matter in the excreta $(\mathrm{g} / \mathrm{kg} \mathrm{DM})^{1}$ & 308.2 & 323.7 & 330.8 & 320.2 & 322.5 & 320.0 & 6.89 & 0.040 & 0.950 & 0.183 \\
\hline Mineral matter in the excreta (g/bird/day $)^{1}$ & 5.95 & 6.32 & 7.00 & 6.40 & 6.38 & 6.49 & 14.86 & 0.049 & 0.685 & 0.267 \\
\hline Calcium consumed $(\mathrm{g} / \mathrm{bird} / \text { day })^{1}$ & 3.53 & 3.79 & 3.93 & 3.68 & 3.75 & 3.83 & 2.39 & $<0.0001$ & 0.245 & 0.540 \\
\hline Calcium excreted $(\mathrm{g} / \mathrm{kg} \mathrm{DM})^{1}$ & 330.6 & 366.6 & 391.5 & 353.5 & 364.9 & 370.3 & 5.42 & $<0.0001$ & 0.431 & 0.103 \\
\hline Calcium excreted (g/bird/day $)^{1}$ & 1.17 & 1.39 & 1.54 & 1.30 & 1.38 & 1.42 & 13.83 & 0.003 & 0.345 & 0.176 \\
\hline Calcium retained $(\mathrm{g} / \mathrm{kg} \mathrm{DM})^{1}$ & 669.3 & 633.3 & 608.4 & 646.4 & 635.0 & 629.6 & 2.26 & 0.021 & 0.313 & 0.098 \\
\hline Calcium retained (g/bird/day) & 2.36 & 2.40 & 2.38 & 2.37 & 2.37 & 2.40 & 7.12 & 0.082 & 0.675 & 0.727 \\
\hline Phosphorus consumed (g/bird/day) ${ }^{1}$ & 0.33 & 0.36 & 0.37 & 0.30 & 0.35 & 0.41 & 2.34 & $<0.0001$ & $<0.0001$ & 0.473 \\
\hline Phosphorus excreted (g/kg DM) & 723.2 & 699.8 & 712.9 & 735.7 & 739.5 & 660.6 & 13.79 & 0.191 & 0.090 & 0.131 \\
\hline Phosphorus excreted (g/bird/day) ${ }^{1}$ & 0.25 & 0.25 & 0.27 & 0.22 & 0.26 & 0.29 & 15.44 & 0.442 & 0.012 & 0.150 \\
\hline Phosphorus retained g/kg DM) & 276.7 & 270.1 & 277.0 & 264.2 & 260.4 & 339.3 & 1.78 & 0.691 & 0.121 & 0.123 \\
\hline Phosphorus retained ( $\mathrm{g} / \mathrm{bird} / \mathrm{day})^{1}$ & 0.09 & 0.11 & 0.09 & 0.08 & 0.09 & 0.12 & 8.23 & 0.091 & $<0.0001$ & 0.704 \\
\hline
\end{tabular}

$\mathrm{CV}$ - coefficient of variation; DM - dry matter; Ca, Rat and $\mathrm{Ca} \times$ Rat - effects from the supplementation with calcium, from the calcium:available phosphorus ratio and their interaction, respectively.

${ }^{1}$ Significant linear effect $(\mathrm{P}<0.05)$. 
$\left(\mathrm{P}<0.05 ; \quad \mathrm{Y}=0.204929+0.0238698 \mathrm{RAT}, \mathrm{r}^{2}=0.94\right)$. As the phosphorus was added to the diet characterized by the decrease in the calcium:phosphorus ratio, there was increase in its excretion. The phosphorus content $(\mathrm{g} / \mathrm{kg}$ of dry matter) in the excreta was not affected by the calcium: phosphorus ratio, which means that the increase of its excretion in $\mathrm{g} / \mathrm{bird} /$ day was proportional to the increase in the concentration of phosphorus in the diet, since it did not affect the concentration ( $\mathrm{g} / \mathrm{kg}$ of dry matter) of this mineral in the excreta. The elevated phosphorus intake, caused by lower calcium:phosphorus ratios in the diet, might have caused an excess of phosphorus in the organism of the bird, which impaired its absorption and increased the losses through feces (Pelícia et al., 2011). In this sense, Ceylan et al. (2003), evaluating the levels of available phosphorus $(4.0 ; 3.5 ; 3.0 ; 2.5$; and $2.0 \mathrm{~g} / \mathrm{kg}+$ phytase $)$ in diets containing $38 \mathrm{~g} / \mathrm{kg}$ of calcium for white egg layers in the period from 20 to 40 weeks of age, also found linear effect from the calcium:phosphorus ratios on the excretion of phosphorus. These authors observed that as the calcium: phosphorus ratios were reduced in the diet characterized by the high levels of phosphorus, the concentration of this mineral in the excreta increased.

The calcium:phosphorus ratios of the diet did not influence $(\mathrm{P}>0.05)$ the content of phosphorus retained $(\mathrm{g} / \mathrm{kg}$ of dry matter) by birds. However, when the retention of this mineral was determined in $\mathrm{g} / \mathrm{bird} /$ day, there was significant difference $(\mathrm{P}<0.05)$ between the calcium: phosphorus ratios evaluated, according to the equation $\mathrm{Y}=0.0540885+0.022854 \mathrm{RAT}\left(\mathrm{r}^{2}=0.89\right)$. These results indicate that the increase in retention in $\mathrm{g} / \mathrm{bird} /$ day was proportional to the elevation in the concentration of phosphorus in the diet, so it did not interfere in the concentration of phosphorus $(\mathrm{g} / \mathrm{kg}$ of dry matter) in the excreta. The results indicate the existence of a direct relationship between the levels of phosphorus supplied and their absorption, within a physiological limit of birds. However, Rosol \& Capen (1997) affirmed that monogastrics have the capacity to develop mechanisms of adaptation which result in increased absorption of phosphorus when it is supplied at low dietary levels. However, this was not observed, probably because the lower level of phosphorus, promoted by the higher calcium:phosphorus ratio, was enough to meet the requirements of birds, so it was not characterized as a low level.

The response pattern of the calcium:phosphorus balance is in line with what was observed for the other variables, because the increase in supplementation of calcium and phosphorus (lower calcium:phosphorus ratio) did not improve the productive parameters, egg quality or bone characteristic of the layers. Although it is known that the calcium and phosphorus levels of a diet for layers are directly related to the quality of the eggshell and bone, in addition to the productive performance of the birds, the decrease in the dietary levels of these minerals should be done cautiously. However, the results from this study indicated that the reduction in the levels of calcium and phosphorus (increase in the calcium:phosphorus ratio) did not impair the quality of shell or bone, or even bird performance. Therefore, it is likely that the marginal level of calcium and the greater calcium:phosphorus ratio utilized were enough to meet the requirements of birds.

\section{Conclusions}

Diets containing calcium at $3.9 \mathrm{~g} / \mathrm{kg}$ and a calcium: available phosphorus ratio of $12.12: 1$, corresponding to a daily intake of $3.51 \mathrm{~g}$ of calcium/bird and $289 \mathrm{mg}$ of available phosphorus/bird, are enough for obtaining satisfactory performance, egg quality and maintenance of the bone tissue for commercial white egg layers in the period from 42 to 58 weeks of age.

\section{References}

ABD EL-MAKSOUD, A. Effect of dietary calcium and vitamin D3 levels on egg production and egg shell quality of Hy-Line Brown - egg type laying hens. Egyptian Poultry Science, v.30, p.1097-1120, 2010.

ALMEIDA PAZ, I.C.L.; MENDES, A.A.; BALOG, A. et al. Efeito do cálcio na qualidade óssea e de ovos de poedeiras. Revista Archivos de Zootecnia, v.58, p.173-183, 2009.

ALMEIDA, R.L.; GOMES, P.C.; ROSTAGNO, H.S. et al. Níveis de cálcio e relação cálcio: fósforo disponível em rações para poedeiras leves no segundo ciclo de produção. In: CONGRESSO APA - PRODUÇÃO E COMERCIALIZAÇÃO DE OVOS, 10., 2012, Ribeirão Preto. Anais... Ribeirão Preto: Associação Paulista de Avicultura, [2012]. (CD-ROM).

BERGGARD, T.; SILOW, M.; THULIN, E. et al. $\mathrm{Ca}^{2+}$ and $\mathrm{H}^{+}$dependent conformational changes of calbindin D28K. Biochemistry, v.39, p.6864-6873, 2000.

BERTECHINI, A.G. Nutrição de monogástricos. 1.ed. Lavras: Editora UFLA, 2006. 301p.

CEYLAN, N.; SCHEIDELER, S.E.; STILBORN, H.L. High available phosphorus corn and phytase in layer diets. Poultry Science, v.82, p.789-795, 2003.

DANTAS, G.M.; SILVA, J.H.V.; SOUZA, J.M.B. et al. Exigência de cálcio para poedeiras leves e semipesadas. In: REUNIÃO ANUAL DA SOCIEDADE BRASILEIRA DE ZOOTECNIA, 47., 2010, Salvador. Anais... Salvador: Sociedade Brasileira de Zootecnia, [2010]. (CD-ROM).

EL-GHAMRY, A.; EL-ALLAWY, M.; HEWIDA, S. et al. Evaluation of dietary calcium requirements in fayoumi laying hens. The Iranian Journal of Applied Animal Science, v.1, p.81-86, 2011.

HY-LINE DO BRASIL. Guia de manejo Hy-Line variedade W36. S.I.: s.n., 2009. 44p.

LELIS, G.R.; TAVERNARI, F.C; CAMPOS, A.M.A. et al. Exigência de fósforo disponível para poedeiras semipesadas no período de 50 a 66 semanas de idade. In: REUNIÃO ANUAL DA SOCIEDADE 
BRASILEIRA DE ZOOTECNIA, 46., 2009, Maringá. Anais... Maringá: Sociedade Brasileira de Zootecnia, [2009]. (CD-ROM).

LICHOVNICOVA, M. The effect of dietary calcium source, concentration and particle size on calcium retention, eggshell quality and overall calcium requirement in laying hens. Bristish Poutry Science, v.48, p.71-75, 2007.

MURATA, L.S.; ARIKI, J.; SANTANA, A.P. et al. Níveis de cálcio e granulometria do calcário sobre o desempenho e a qualidade da casca de ovos de poedeiras comerciais. Revista Biotemas, v.22, p.103-110, 2009.

PELÍCIA, K.; MOURÃO, J.L.M.; GARCIA, E.A. et al. Effects of dietary calcium levels and limestone particicle size on the performance, tibia and blood of laying hens. Brazilian Journal of Poultry Science, v.13, p.29-34, 2011.

PELÍCIA, K.; GARCIA, E.A.; MÓRI, C. et al. Calcium levels and limestone particle size in the diet of commercial layers at the end of the first production cycle. Brazilian Journal of Poultry Science, v.11, p.87-94, 2009b.

PELÍCIA, K.; GARCIA, E.A.; FAITARONE, A.B.G. et al. Calcium and available phosphorus levels for laying hens in second production cycle. Brazilian Journal of Poultry Science, v.11, p.39-49, 2009a.

ROSA, P.A.; FERREIRA, P.B.; NOEBAUER, M.R. et al. Diferentes relações cálcio:fósforo disponíveis e fitase em dietas de poedeiras UFSM-V: desempenho produtivo, qualidade dos ovos e tecido ósseo. Ciência Rural, v.41, p.1831-1837, 2011.

ROSOL, T.J.; CAPEN, C.C. Calcium-regulating hormones and diseases of abnormal mineral (calcium, phosphorus, magnesium) metabolism. In: KANEKO, J.J.; HARVEY, J.W.; BRUSS, M.L. (Eds.) Clinical biochemistry of domestic animals. 5.ed. San Diego: Academic Press, 1997. p.619-702.

RAMA-RAO, S.V.; PANDA, A.K.; RAJU, M.V.N. et al. Requirement of calcium for commercial broilers and white leghorn layers at low dietary phosphorus levels. Animal Feed Science and Technology, v.106, p.199-208, 2003.

REZENDE, J.C.R.; BRESNE, C.; LAURENTIZ, A.C. [2009]. Características ósseas de poedeiras recebendo rações com níveis reduzidos de fósforo suplementadas com fitase. In: CONGRESSO DE INICIAÇÃO CIENTÍFICA DA UNESP, 21., 2009, São José do Rio Preto. Anais eletrônicos... São José do Rio Preto: Universidade Estadual Paulista "Júlio de Mesquita Filho", 2009.
Available at: <http://prope.unesp.br/xxi_cic/27_ 36846204830. pdf $>$ Accessed on: May 20, 2010.

ROLAND, D.A.; SLOAN, D.R.; HARMS, R.H. The ability of hens to maintain calcium deposition in the eggshell and egg yolk as the hen ages. Poultry Science, v.54, p.1720-1723, 1975.

ROSTAGNO, H.S.; ALBINO, L.F.T.; DONZELE, J.L. et al. Tabelas brasileiras para aves e suínos - Composição de alimentos e exigências nutricionais. 2.ed. Viçosa, MG: Universidade Federal de Viçosa, 2005. 186p.

ROSTAGNO, H.S.; ALBINO, L.F.T.; DONZELE, J.L. et al. Tabelas brasileiras para aves e suínos - Composição de alimentos e exigências nutricionais. 3.ed. Viçosa, MG: Universidade Federal de Viçosa, 2011. 252p.

SAFAA, H. M.; SERRANO, M. P.; VALENCIA, D. G. et al. Productive performance and egg quality of brown egg-laying hens in the late phase of production as influenced by level and source of calcium in the diet. Poultry Science, v.87, p.2043-2051, 2008.

SALAMA, A.A.; EL-SHEIKH, E.M. Effect of dietary protein and calcium level on productive performance of local laying hens under desert conditions. Egyptian Poultry Science, v.32, p.75-93, 2012.

SCHREIWEIS, M.A.; ORBAN, J.I.; LEDUR, M.C. et al. The use densitometry to detect differences in bone mineral density and content of live white Leghorns fed varying levels of dietary calcium. Poultry Science, v.82, p.1292-1301, 2003.

SILVA, D.J.; QUEIROZ, A.C. Análises de alimentos - Métodos químicos e biológicos. 3.ed. Viçosa, MG: Universidade Federal de Viçosa, 2002. 235p.

SILVA, J.H.V.; ARAUJO, J.A.; GOULART, C.C. et al. Relação cálcio: fósforo disponível e níveis de fitase para poedeiras semipesadas no primeiro e segundo ciclos de postura. Revista Brasileira de Zootecnia, v.37, p.2166-2172, 2008.

VIEIRA, M.M.; KESSLER, A.M.; RIBEIRO, A.M.L. et al. Nutrient balance of layers fed diets with different calcium levels and the inclusion of phytase and/or sodium butyrate. Brazilian Journal of Poultry Science, v.13, p.157-162, 2011.

VELLASCO, C.R.; GOMES, P.C.; DONZELE, J.L. et al. Níveis de cálcio e relação cálcio/fósforo em rações para poedeiras leves de 24 a 40 semanas de idade In: REUNIÃO ANUAL DA SOCIEDADE BRASILEIRA DE ZOOTECNIA, 47., 2010. Salvador. Anais... Salvador: Sociedade Brasileira de Zootecnia, [2010]. (CD-ROM). 